\title{
Altered Expression of Aromatase, Estrogen Receptors and Progesterone Receptors in Human Leydig Cell Hyperplasia
}

\author{
Candela Rocío González ${ }^{*}$, Pablo Ignacio Felipe Inserra ${ }^{1}$, Claudio Terradas ${ }^{2}$, \\ Roberto Ponzio ${ }^{3}$, Elisa Puigdomenech ${ }^{4}$, Oscar Levalle ${ }^{2}$, Alfredo Daniel Vitullo ${ }^{1}$, \\ Ricardo Saúl Calandra ${ }^{5}$, Silvia Ines Gonzalez-Calvar ${ }^{6}$ \\ ${ }^{1}$ Research Center of Biomedical Biotechnology, Environmental and Diagnostic Studies, Maimónides University, \\ Buenos Aires, Argentina \\ ${ }^{2}$ División Endocrinología, Hospital Durand, Buenos Aires, Argentina \\ ${ }^{3}$ Facultad de Medicina, Universidad de Buenos Aires, Buenos Aires, Argentina \\ ${ }^{4}$ Instituto Medico PREFER, Calle 995 № 2348, San Martin, Argentina \\ ${ }^{5}$ Laboratorio de Endocrinología Molecular de la Reproducción, Instituto de Biología y Medicina Experimental \\ (CONICET), Buenos Aires, Argentina \\ ${ }^{6}$ Laboratorio de Endocrinología Molecular de la Reproducción, Instituto de Biología y Medicina Experimental \\ (CONICET), Facultad de Medicina, Universidad de Buenos Aires, Buenos Aires, Argentina \\ Email: "gonzalez.candela@maimonides.edu, ${ }^{*}$ cande00@hotmail.com
}

Received 2 December 2014; revised 25 December 2014; accepted 6 January 2015

Copyright (C) 2015 by authors and Scientific Research Publishing Inc.

This work is licensed under the Creative Commons Attribution International License (CC BY).

http://creativecommons.org/licenses/by/4.0/

(c) (i) Open Access

\section{Abstract}

Testicular function is regulated by pituitary hormones and also by paracrine and autocrine factors. A number of reports have pointed out the importance of estrogens and progesterone in male reproductive tract. Recently, we have reported in testicular biopsies from men with Sertoli Cell Only Syndrome (SCO) or Hypospermatogenesis (H) with Leydig cell hyperplasia (LCH) an increase in the expression of the TGFB1 and its receptors $A L K 1$ and endoglin, which are involved in the proliferation of Leydig cells. The aim of the present work was to analyze the expression of aromatase, estrogen and progesterone receptors (ERs, PR) in pathological testicular biopsies with SCO or H with and without LCH. The ERs and CYP19 proteins were detected in the Leydig cells from all pathological biopsies analyzed. Biopsies with SCO or H with LCH showed an increment in the immunostaining of CYP19 and ERs in the Leydig cells respect to biopsies without LCH. The gene expression of CYP19 was increased in SCO or H biopsies with LCH respect to SCO and H biopsies without LCH. PR was localized in Leydig cells and showed a significant increment in biopsies with LCH respect from biopsies without LCH. The gene expression of both PRA and PRB was increased

${ }^{*}$ Corresponding author.

How to cite this paper: González, C.R., et al. (2015) Altered Expression of Aromatase, Estrogen Receptors and Progesterone Receptors in Human Leydig Cell Hyperplasia. Advances in Bioscience and Biotechnology, 6, 1-10.

http://dx.doi.org/10.4236/abb.2015.61001 
in biopsies with LCH respect to biopsies without LCH. In concussion, alterations in the gene expression of aromatase, ERs, and PR and the likely interactions of these systems with locally produced factors such as growth factors and cytokines, might lead to Leydig cell proliferation in testicular pathology.

\section{Keywords}

\section{Aromatase, Progesterone, Estrogen, Leydig}

\section{Introduction}

Testis exerts two main functions: steroidogenesis and spermatogenesis, which are both finely regulated by endocrine, autocrine and paracrine factors. While testosterone is the main steroid produced by testis, estrogens and progesterone are also synthesized by male gonads. A number of reports have pointed out the importance of these hormones in male reproductive tract [1]-[4].

The synthesis of estrogens is catalyzed by aromatase enzyme encoded by CYP19 gene. Although it has been reported that aromatase is expressed in germ cells and spermatids [5], Leydig cells have been identified as the major site of expression in the testis [3] [6] [7]. Aromatase activity has been shown to be controlled not only by $\mathrm{LH}$, cyclic AMP and testosterone, but also by local factors.

Estrogens exert their effects by the interaction with two different receptors, estrogen receptor $\alpha$ and $\beta$ (ERalpha and ERbeta) [8]. The presence of $\mathrm{ER} \alpha$ and $\beta$ in human testis has been extensively described [5] [7]. However, not all studies have agreed in ER localization or expression for the same type of cells. This discrepancy might be due either to the occurrence of a number of $\mathrm{ER} \alpha$ and $\beta$ isoforms or to the diverse antibodies employed in the studies [9]. In mice testis, ERs $\alpha$ and $\beta$ modulate the cell proliferation and the steroidogenic process [10].

The transcriptional responses to estrogenic signalling depend on the concentration and cellular localization of ERs. It is now known that ERs function as dimers, and co-expression of ER $\alpha$ and $\operatorname{ER} \beta$ in a given cell may lead to an interaction between these two receptors [11]. In this context, it has been shown that ER $\alpha$ and $\beta$ can modulate gene transcription by themselves or, in an indirect way; i.e. $\mathrm{ER} \beta$ can regulate the ER $\alpha$ action enhancing or repressing gene transcription [12] [13].

The role of progesterone in male reproductive physiology has not yet been established. It has been described that progesterone regulates the spermatogenic process [14] [15], and the steroidogenesis in Leydig cells by the modulation of Star expression [16]. Progesterone receptors (PR) have been described in spermatozoa of different species including adult human testis [17]-[20]. However there are scan information about the action of progesterone on Leydig cell function [21].

Genomic PR is expressed in two major isoforms, named PRA and PRB, which are the product of two different transcriptional start sites [1] [22]. PRA and PRB have, to some extent, different functions. PRA act generally as a repressor of PRB, while PRB is a strong activator of target genes [23].

Azoopermic men (non-obstructive azoospermia) generally present either Sertoli Cell Only Syndrome (SCO) or Hypospermatogenesis (H). A group of these patients also have Leydig cell hyperplasia (LCH), which is a benign condition that occur either as multifocal nodules, often bilateral or diffuse [24] [25].

Recently, Gonzalez et al. have reported the involvement of progesterone in transforming growth factor beta 1 (TGF- $\beta 1$ ) action on TM3 Leydig cell proliferation by inducing the co-receptor endoglin [26]. Furthermore, these authors have also demonstrated the expression of TGF- $\beta 1$ system in testicular biopsies from men with SCO or $\mathrm{H}$ [27], and have observed that patients with SCO or $\mathrm{H}$ who also present $\mathrm{LCH}$ showed that the expression of TGF- $\beta 1$ mRNA was higher than SCO or H patients without LCH. They have described the presence of endoglin, the co-receptor of $A L K-1$ (TGFB1 type I receptor), in human Leydig cells and a positive correlation between $A L K 1$ and endoglin, suggesting that these proteins might be involved in the hyperplasia/hypertrophy of Leydig cells [27].

The aim of the present study was to analyze the expression profiles of aromatase, ER and PR in pathological testicular biopsies with SCO or $\mathrm{H}$ with and without $\mathrm{LCH}$. We studied the differential pattern of expression of the $\mathrm{ER} \alpha$ and $\mathrm{ER} \beta$ isoforms as well as PRA and PRB isoforms and their involvement on Leydig cell hyperplasia. 


\section{Material and Methods}

\subsection{Patients and Testicular Biopsies}

The present study was considered in accordance with the Helsinki Declaration and its last modification in Tokyo 2004 on human experimentation and was approved by The Ethical Committee of the Durand Hospital (Buenos Aires, Argentina) and Ethical Committee of the Instituto de Biología y Medicina Experimental (accredited provision \# 4-DGDOIN-2012 and \# 46 to the Central Committee of Ethics in Research, Ministry of Health, Ciudad Autónoma de Buenos Aires, Argentina). Informed Consent was obtained from every patients enrolled in the study (between the years 2006-2010).

Nineteen men (27 - 42 years old) presenting idiopathic infertility and non-obstructive azoospermia without infection process were included in this study and were assessed and diagnosed by open testicular biopsy. Those patients that presented known etiology of infertility, such as genitourinary infections, mumps orchitis, varicocele, hypogonadotropic hypogonadism, chromosome anomalies, obstruction or agenesia of seminal ducts were excluded.

Azoospermia diagnosis was determined by the analysis of at least two semen samples collected at different times. Two replicates of each sample were centrifuged at $3000 \times \mathrm{g}$ for $15 \mathrm{~min}$. A detailed physical examination, endocrinology profile testing and a testicular biopsy were performed to every patient. Those patients included in this study presented normal cariotype. It was considered non-obstructive azoospermia to the presence of defects in spermatogenesis in testicular biopsy without evidence of obstruction in the ejaculatory ducts. All the patients underwent diagnostic testicular biopsy or sperm retrieval and agreed to supply a piece of testicular tissue (5 mm in diameter) for further studies. Tissue was fixed in Bouin's solution and subjected to histopathological diagnosis. The testicular histopathology was categorized according to the most advanced presence of spermatogenesis. Two pathologists evaluated all testicular slices. Biopsies were classified either as H or SCO appearance, according to McLachlan et al. [28]. The H group included men in which the biopsy specimens contained less than 17 mature spermatids per tubule [29] [30]. The LCH group presented more than 7 Leydig clusters of more than 15 cells per $3.14 \mathrm{~mm}^{2}$, in four fields of vision with a $20 \times$ objective [31]. Briefly, biopsies were classified as SCO $(n=6)$, SCO + LCH $(n=2), H(n=8)$ and H + LCH $(n=3)$ according to testicular morphology. Twothirds of the volume of pathological samples was cryopreserved in liquid nitrogen for molecular biology studies.

\subsection{Immunohistochemistry of Human Testicular Tissue}

Bouin's fixed human testicular biopsies were dehydrated, embedded in paraffin and sectioned at $5 \mu \mathrm{m}$. Hematoxylin/eosin stain was used to analyze testicular morphology. The sections were deparaffinized with $100 \%$ xylene and sequentially rehydrated with $96 \%, 90 \%, 80 \%$ and $70 \%$ ethanol. Endogen peroxydase was blocked with $3 \%$ hydrogen peroxide in absolute methanol for 5 min, washed twice with phosphate-buffered saline (PBS, pH 7.4) for 5 min each time. The sections were subjected to saponine (0.5\%) treatment. Nonspecific binding was blocked with normal serum blocking buffer for $20 \mathrm{~min}$ at room temperature. The slides were incubated over night with the primary antibodies 1:200 diluted rabbit anti-aromatase (ab18995, Abcam, UK) or 1:200 diluted rabbit anti-PR (C-19, sc-538, Santa Cruz Biotechnology) at $4^{\circ} \mathrm{C}$ ON. Then, samples were incubated with the appropriated 1:200 biotynilated secondary antibody (Vector Labs) and the colour reaction was amplified with kit ABC (Vector Labs) and 0.055\% w/v 3,3'-diaminobenzidine and 0.1\% v/v H2O2 in Tris-HCl. Negative controls were processed simultaneously by omitting the primary antibodies and were treated with preimmune serum.

\subsection{Double Immunofluorescence of Human Testicular Tissue}

Dewaxed and rehidrated tissue sections were blocked for $1 \mathrm{~h}$ with 15\% normal goat serum in PBS and then incubated overnight at $4^{\circ} \mathrm{C}$ with primary antibody 1:100 diluted rabbit anti-ER $\beta$ (ab3577, Abcam). After three rinses in PBS, sections were incubated for $1 \mathrm{~h}$ at room temperature with the appropriated 1:300 diluted anti rabbit Alexa Fluor (Invitrogen, Carlsbad, CA, USA). After further washing in PBS, sections were incubated overnight at $4^{\circ} \mathrm{C}$ with the primary antibody 1:200 diluted rabbit anti-ER $\alpha$ (MC-20, sc-542, Santa Cruz Biotechnology). After three rinses in PBS, sections were incubated in the dark for $1 \mathrm{~h}$ at room temperature with 1:300 diluted FITC anti-rabbit IgG $(\mathrm{H}+\mathrm{L})$ conjugate (Zymed Laboratories, San Francisco, CA, USA). After further washing in PBS, slides were mounted with DAKO fluorescence mounting medium (DAKO, USA) and analyzed by using a Nikon C1 D-Eclipse Confocal microscope coupled to Ti Eclipse Fluorescence system. Negative con- 
trols were processed simultaneously by omitting the primary antibodies or pre-absorbing the primary antibody with synthetic peptides.

\subsection{Image Analysis}

Six sections of each sample were analyzed. Microscope images of aromatase immunoreactivity were captured with an optic microscope (BX40, Olympus Optical Corporation, Tokyo, Japan), fitted with a digital camera (390CU 3.2 Megapixel CCD Camera, Micrometrics, Spain), while ER $\alpha$ and $\beta$ and PR immunoreactivity were captured with a Nikon C1 D-Eclipse Confocal microscope coupled to Ti Eclipse Fluorescence system. In both cases, images were analyzed using Image-Pro Plus software (Image-Pro Plus 6, Media Cybernetics Inc., Bethesda, Maryland, USA) and the integrated optical density was measures. All images were taken the same day under the same light to avoid external variations.

\subsection{Testicular RNA Isolation and Quantitative Real Time PCR}

Total RNA from human biopsies was extracted with Trizol (Invitrogen) according to the manufacturer's instructions. Total RNA (1 ug) was treated with DNAseI (Invitrogen). Reverse transcription reaction was carried out in a $20 \mu \mathrm{l}$ reaction using M-MLV reverse transcriptase (Promega, $200 \mathrm{U} / \mathrm{ul}$ ) and random hexamers primers (Biodynamics).

Reverse-transcribed cDNAs were used to amplify mRNA sequences in a Stratagene MPX500 cycler (Stratagene, USA), using SYBR Green Master Mix Reagent (Applied Biosystems). The forward (F) and reverse (R) human primers were: aromatase (NM_000103.3): F: 5' CTAAATTGCCCCCTCTGAG 3' and R: 5'CCACACCAAGAGAAAAAG 3'; PRA-B (NM_001202474.3): F: 5' ACACCTTGCCTGAAGTTT 3' and R: 5' CTGTCCTTTTCTGGGGGA 3'; PRB (NM_001202474.2): F: 5' GAGGATAGCTCTGAGTCC 3' and R: 5' TTTGCCCTTCAGAAGCGG 3' and GAPDH (NM_002046.4) F: 5' TGCACCACCAACTGCTTAGC 3' and R: 5'GGCATGGACTGTGGTCATGAG 3'. Each primer was used at a concentration of $0.3 \mu \mathrm{M}$ in each reaction. Cycling conditions were as follows: step 1,10 min at $95^{\circ} \mathrm{C}$; step 2,15 sec at $95^{\circ} \mathrm{C}$; step 3,30 sec at $55^{\circ} \mathrm{C}$; step 4 , $30 \mathrm{sec}$ at $60^{\circ} \mathrm{C}$, repeating from step 2 to step 440 times. Data from the reaction were collected and analyzed by the complementary computer software (Sequence Detection Software, Applied Biosystems, Version 1.3). Melting curves were run to confirm specificity of the signal. Relative quantification of gene expression was calculated using standard curves and normalized to GADPH in each sample.

Quantitative differences in cDNA target between samples were assessed by the mathematical model of Pfaffl [32]. An expression ratio was determined for each sample by calculating (Etarget) $\Delta \mathrm{Ct}(\operatorname{target}) /(\mathrm{EGAPDH}) \Delta \mathrm{Ct}(\mathrm{GAPDH})$, where $\mathrm{E}$ is the efficiency of the primer set and $\Delta \mathrm{Ct}=\mathrm{Ct}$ (normalization cDNA) - $\mathrm{Ct}$ (experimental cDNA). The amplification efficiency of each primer set was calculated from the slope of a standard amplification curve of $\log (\mathrm{ng}$ cDNA) per reaction vs. Ct value $(\mathrm{E}=10$ - (1/slope)). Efficiencies of $2 \pm 0.1$ were considered optimal.

\subsection{Statistical Analysis}

Mean and standard error (SEM) were calculated and Graph Pad Prism Software (version version 5.0 for Windows, GraphPad Software, San Diego, CA, USA) was used for one-way analysis of variance. Newman-Keuls test was used when differences between more than two groups were compared. A p-value of less than 0.05 was considered significant.

\section{Results}

\subsection{Aromatase and ER $\alpha$ and $\beta$ Expression in Human Testicular Pathologies}

Cytoplasmic aromatase immunostaining (Figure 1, Panel A) was detected in Leydig and Sertoli cells from all biopsies studied. The intensity of aromatase immunostaining in Leydig cells was higher in patients with LCH compared with patients without LCH (SCO + LCH vs SCO: 5 fold, p < 0.05; H + LCH vs H: 5.6 fold, p < 0.05). CYP19 mRNA expression clearly showed a significant increase in testicular biopsies from LCH group (independently of whether LCH derived from SCO or H) respect to biopsies without LCH $(p<0.05)$ (Figure 1, Panel B).

Figure 2 shows the co-localization by immunofluorescence of ER $\alpha$ and ER $\beta$ in pathological testicular biopsies. ER $\alpha$ was detected mainly in the cytoplasm of Leydig cells in all biopsies studied. ER $\alpha$ nuclear staining 


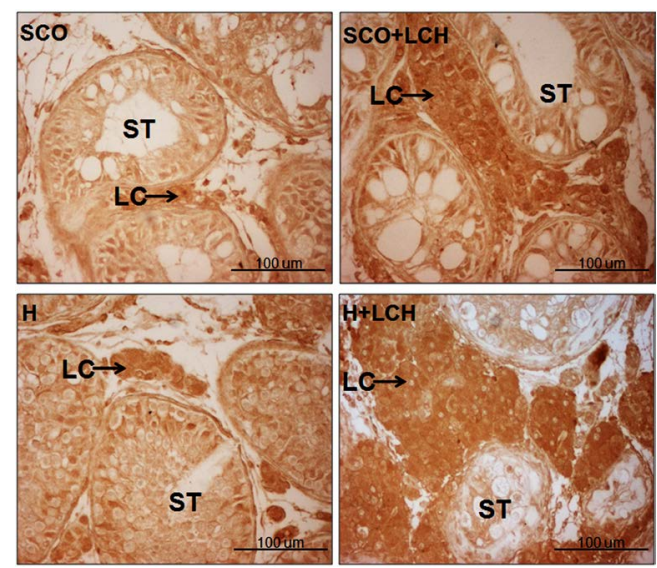

(A)

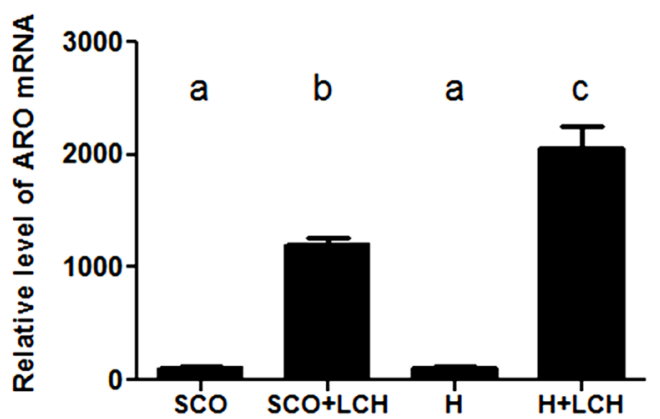

(B)

Figure 1. Immunolocalization of aromatase (A) and CYP19 mRNA expression (B) in human testicular pathologies. (B) Expression of CYP19 mRNA measure by real time PCR. Different letters indicate significant differences between groups $(\mathrm{p}<0.05)$. All results are expressed relative to the housekeeping $(G A D P H)$ gene expression as arbitrary units. Data are plotted as the mean \pm SEM. H: Hypospermatogenesis; SCO: Sertoli cell-only syndrome; LCH: Leydig Cell Hyperplasia; ST: Seminiferous tubules; LC: Leydig cell.

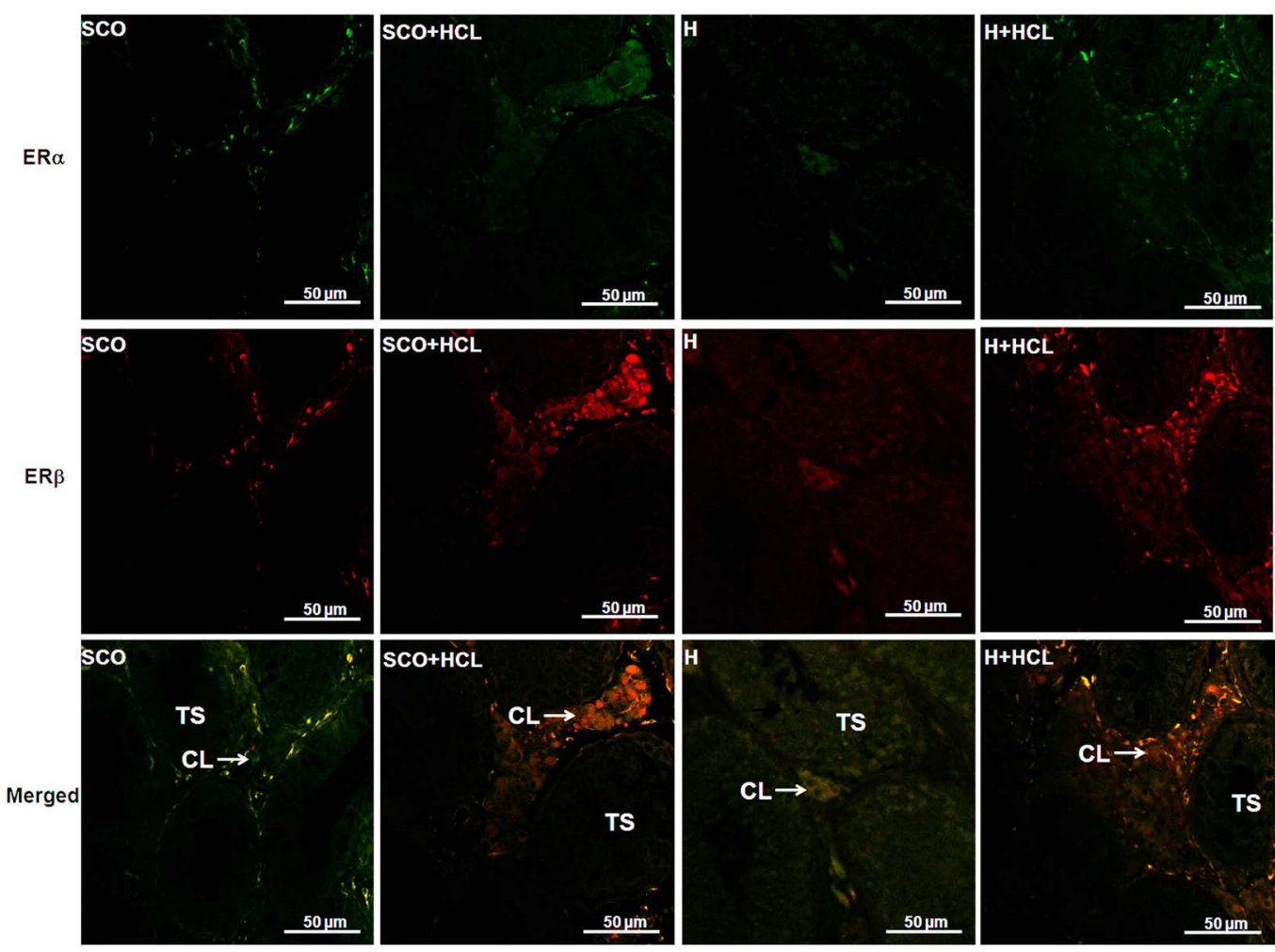

Figure 2. Double color immunofluorescence of estrogen receptor $\alpha$ and $\beta$ in human testicular pathologies. $\mathrm{ER} \alpha$ : green color; ER $\beta$ : red color. H: Hypospermatogenesis; SCO: Sertoli cell-only syndrome; LCH: Leydig cell h yperplasia; ST: Seminiferous tubules; LC: Leydig cell.

was observed in some Sertoli cells and germ cells in biopsies from $\mathrm{H}$ or $\mathrm{H}+\mathrm{LCH}$ patients (Figure 2). The intensity of ER $\alpha$ immunostaining in Leydig cells from biopsies with LCH was higher than in biopsies without LCH (SCO + LCH vs SCO: 4 fold, p < 0.05; H + LCH vs H: 5 fold, p < 0.05).

$\mathrm{ER} \beta$ was observed mainly in the cytoplasm of Leydig cells in all biopsies analyzed (Figure 2). Nuclear immunostanning was detected in some Leydig cells. No immunostaining of $\operatorname{ER} \beta$ was observed in the seminiferous 
tubules of biopsies with SCO and LCH + SCO. Low nuclear staining of some Sertoli cells and germ cells was observed in biopsies with $\mathrm{H}$ and $\mathrm{H}+\mathrm{LCH}$ (Figure 2). The intensity of ER $\beta$ immunostaining in Leydig cells from biopsies with LCH was higher than in biopsies without LCH (SCO + LCH vs SCO: 2.3 fold, p < 0.05; H + LCH vs $\mathrm{H}$ : 7 fold, $\mathrm{p}<0.05)$.

\subsection{Immunostaining of PR and PRA and PRB Gene Expression in Testicular Pathologies}

Total PR was mainly detected in the cytoplasm Leydig cells of all biopsies studied (Figure 3, Panel A). PR was detected in the nucleus of some germ cells and with a lesser degree in the cytoplasm of Sertoli cells within the seminiferous tubules (Figure 3, Panel A). The intensity of PR immunostaining in Leydig cells was higher in patients with LCH compared with patients without LCH (SCO + LCH vs SCO: 5.2 fold, p < 0.05; H + LCH vs H: 3.8 fold, $\mathrm{p}<0.05)$.

The two isoforms of the PR were measure by real time PCR in pathological testicular biopsies.

PRA and PRB mRNA expression showed a significant increase in testicular biopsies from LCH group, independently of whether LCH derived from SCO or H. (Figure 3, Panel B).

\section{Discussion}

The relevance of estrogens and progesterone in male reproductive system has been acutely documented [1] [4]. However, the precise role of these hormones in testicular function and the regulation of their biosynthesis is still an issue of research. In this context, aromatase and ERs have been detected not only in testis of normal tissue but also in testicular pathologies [8] [33]-[35]. Besides, estrogens have been involved in cell proliferation even in Leydig cells [36].

Aromatase has been detected in somatic cells, germ cells and spermatids both in experimental animal models and humans [37]. In the present study, aromatase expression observed by immunohistochemistry was localized in both Leydig and Sertoli cells. Particularly, in Leydig cells of biopsies from patients with LCH the immunostaining of aromatase was higher than in patients with SCO or $\mathrm{H}$ without $\mathrm{LCH}$. Furthermore, these results were corroborated by evaluating CYP19 mRNA expression in the biopsies. Lardone et al. [38] have reported that CYP19 mRNA and aromatase activity correlates positively with the Leydig cell number in patients with SCO or Maturation Arrest. Moreover, it has been shown that transgenic mice that over express the aromatase gene (ARO+) present hyperplasia of Leydig cells [39] [40].

$\mathrm{ER} \alpha$ and $\beta$ were detected in all biopsies studied. Despite some reports have found no ER $\alpha$ immunostaining in human testis [41] [42], others reports have detected both isoforms of ERs in human testicular pathologies in agreement with the results presented in this study. These discrepancies might be due to the protocol, antibodies used or to the different ER isoforms present in the tissue analyzed [9]. Although ER localization is becoming clear, the physiological functions mediated by each receptor are not well defined. It has been long described that ERs exert their action as transcriptional factors [43].

However, in all testicular biopsies analyzed, ER $\alpha$ presented a cytoplasmic localization in Leydig cells whereas ER $\beta$ presented a cytoplasmic and nuclear localization. These results suggest that ER $\beta$ would exert its action via a classical signalling pathway acting as transcription factor. The cytoplasmic localization of ER $\alpha$ prompts us to speculate that this receptor might act in concert with GPR30, the membrane associated ER [44], as was suggested by Albanito et al. [45] who have reported the presence of a complex interplay between GPR30 and ER $\alpha$.

In the present study, the immunostaning expression of $\operatorname{ER} \beta$ was higher than ER $\alpha$ in biopsies which present LCH. In agreement with these results, Kauffman et al. [46] have described that in bladder cancer cell lines ER $\beta$ leads to a significant increase in cell proliferation. In this context, Carpino et al. [47] have observed a high expression of ER $\beta$ in Leydig cell tumors in humans. However, it has been reported that $\beta$ ERKO mice present Leydig cell proliferation and $\alpha$ ERKO mice only show hypertrophy of these cells [13]. Moreover, Du Mond et al. [48] have reported that estrogens were able to induce the proliferation of TM3 Leydig cells via ER $\alpha$.

The total PR protein was mainly localized in the cytoplasm of Leydig cells of all testicular pathological biopsies analyzed and with a higher staining observed in the Leydig cells from the LCH groups. Both PRA and PRB gene expression were increased in biopsies with SCO and H with LCH respect to biopsies without LCH. This suggests that Leydig cells are target sites of progesterone action. Although the intratesticular levels of progesterone are unknown, it is plausible that the progesterone synthesized in Leydig cells might act in an autocrine or paracrine manner regulating somatic and spermatogenic cells function. 


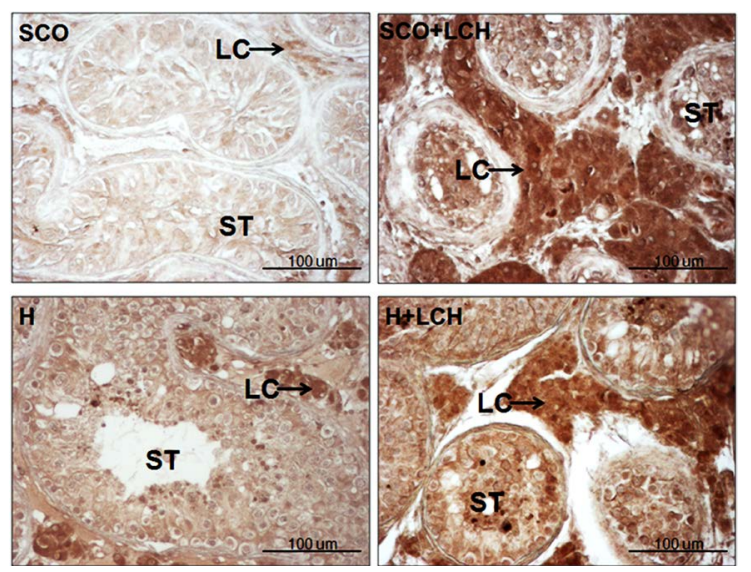

(A)
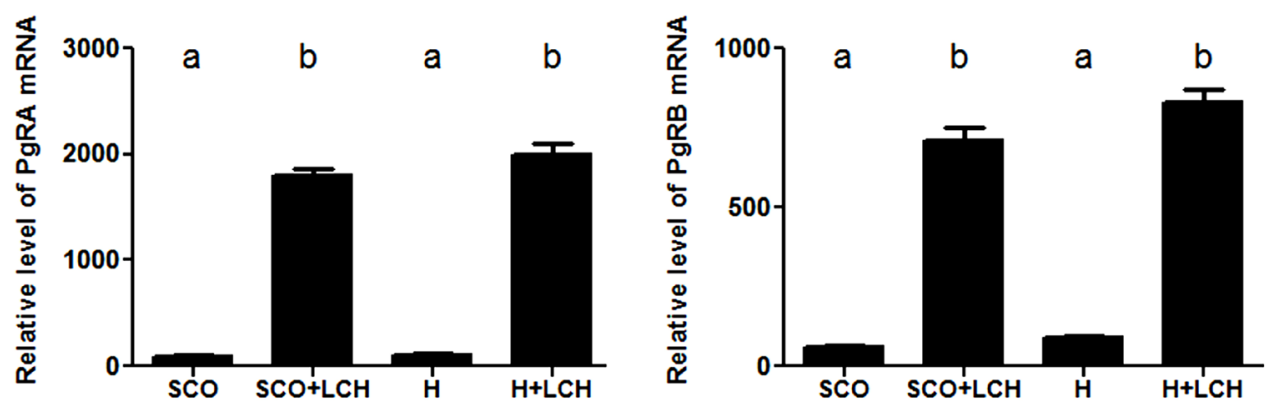

(B)

\begin{abstract}
Figure 3. Immunolocalization (A) and mRNA expression (A) of progesterone receptors (PR) in human testicular pathologies. (B) Expression of PRA and PRB mRNA measure by real time PCR. Different letters indicate significant differences between groups $(\mathrm{p}<0.05)$. All results are expressed relative to the housekeeping $(G A D P H)$ gene expression as arbitrary units. Data are plotted as the mean \pm SEM. H: Hypospermatogenesis, SCO: Sertoli cell-only Syndrome, LCH: Leydig cell hyperplasia, ST: Seminiferous tubules, LC: Leydig cell.
\end{abstract}

Recently, Gonzalez et al. [26] have reported that in mouse Leydig cells progesterone induces endoglin, the co-receptor of TGF- $\beta 1$, leading to cell proliferation. Furthermore, these authors have reported that testicular biopsies with LCH presented an increase in the expression of TGF- $\beta 1$ and their receptors, particularly ALK1 and endoglin, [27]. The effect that TGF- $\beta 1$ exerts on the proliferation of Leydig cells depends on the cellular context; i.e., the presence of factors such as the concentration of this cytokine in the cell environment, and more importantly, the type of receptors and co receptors present in the Leydig cells [49]. Taking together these observations we are prompt to speculate that the presence of PR in human Leydig cells might be involved in the proliferation of Leydig cells.

\title{
5. Conclusion
}

Estrogens and progesterone are important in the regulation of the male reproductive tract, with clear evidence pointing to a direct effect on the function of Leydig cells. Both hormones acting in concert with locally produced factors such as growth factors and cytokines could modulate the activity of these cells leading to proliferative responses. However, the mechanisms of action of estrogens and progesterone remain to be clarified and these data open new considerations in the analysis of the testes in physiological and pathophysiological conditions.

\section{Acknowledgements}

This study was supported by Grants from Consejo Nacional de Investigaciones Científicas y Técnicas (CONICET, PIP \#150), Agencia Nacional de Promoción Científica y Técnica (ANPCyT; PICT \#414) and Fundacion Cientifica Felipe Fiorellino. 


\section{References}

[1] Gadkar-Sable, S., Shah, Ch., Rosario, G., Sachdeva, G. and Puri, Ch. (2005) Progesterone Receptors: Various Forms and Functions in Reproductive Tissues. Frontiers in Bioscience, 10, 2118-2130. http://dx.doi.org/10.2741/1685

[2] Carreau, S., Bois, C., Zanatta, L., Silva, F.R.M.B., Bouraima-Lelong, H. and Delalande, C. (2011) Estrogen Signaling in Testicular Cells. Life Sciences, 89, 584-587. http://dx.doi.org/10.1016/j.lfs.2011.06.004

[3] Sharpe, R.M. (1998) The Role of Oestrogens in the Male. Trends in Endocrinology and Metabolism, 9, 371-377. http://dx.doi.org/10.1016/S1043-2760(98)00089-7

[4] Hess, R.A. (2003) Estrogen in the Adult Male Reproductive Tract: A Review. Reproductive Biology and Endocrinolology, 1, 52. http://dx.doi.org/10.1186/1477-7827-1-52

[5] O’Donnell, L., Robertson, K.M., Jones, M.E. and Simpson, E.R. (2001) Estrogen and Spermatogenesis. Endocrine Reviews, 22, 289-318. http://dx.doi.org/10.1210/er.22.3.289

[6] Hess, R.A., Gist, D.H., Bunick, D., Lubahn, D.B., Farrell, A., Bahr, J., Cooke, P.S. and Greene, G.L. (1997) Estrogen Receptor ( $\mathrm{a}$ and $\mathrm{b}$ ) Expression in the Excurrent Ducts of the Adult Male Rat Reproductive Tract. Journal of Andrology, 18, 602-611.

[7] Hess, R.A., Bunick, D. and Bahr, J. (2001) Oestrogen, Its Receptors and Function in the Male Reproductive Tract-A Review. Molecular and Cellular Endocrinology, 178, 29-38. http://dx.doi.org/10.1016/S0303-7207(01)00412-9

[8] Conley, A. and Hinshelwood, M. (2001) Mammalian Aromatases. Reproduction, 121, 685-695. http://dx.doi.org/10.1530/rep.0.1210685

[9] Cavaco, J.E., Laurentino, S.S., Barros, A., Sousa, M. and Socorro, S. (2009) Estrogen Receptors Alpha and Beta in Human Testis: Both Isoforms Are Expressed. Systems Biology in Reproductive Medicine, 55, 137-144. http://dx.doi.org/10.3109/19396360902855733

[10] Gould, M.L., Hurst, P.R. and Nicholson, H.D. (2007) The Effects of Oestrogen Receptors $\alpha$ and $\beta$ on Testicular Cell Number and Steroidogenesis in Mice. Reproduction, 134, 271-279. http://dx.doi.org/10.1530/REP-07-0025

[11] Akingbemi, B.T. (2005) Estrogen Regulation of Testicular Function. Reproductive Biology and Endocrinology, 3, 5164. http://dx.doi.org/10.1186/1477-7827-3-51

[12] Hall, J.M. and McDonnell, D.P. (1999) The Estrogen Receptor Beta-Isoform (ERBeta) of the Human Estrogen Receptor Modulates ERa Transcriptional Activity and Is a Key Regulator of the Cellular Response to Estrogens and Antiestrogens. Endocrinology, 140, 5566-5578.

[13] Chang, E.C., Frasor, J., Komm, B. and Katzenellenbogen, B.S. (2006) Impact of Estrogen Receptor on Gene Networks Regulated by Estrogen Receptor in Breast Cancer Cells. Endocrinology, 147, 4831-4842. http://dx.doi.org/10.1210/en.2006-0563

[14] Shah, C., Modi, D., Sachdeva, G., Gadkar, S. and Puri, C. (2005) Coexistence of Intracellular and Membrane-Bound Progesterone Receptors in Human Testis. Journal of Clinical Endocrinology and Metabolism, 90, 474-483. http://dx.doi.org/10.1210/jc.2004-0793

[15] Calogero, A.E., Burrello, N., Barone, N., Palermo, I., Grasso, U. and D’Agata, R. (2000) Effects of Progesterone on Sperm Function: Mechanism of Action. Human Reproduction, 15, 28-45. http://dx.doi.org/10.1093/humrep/15.suppl_1.28

[16] Schwarzenbach, H., Manna, P.R., Stocco, D.M., Chakrabarti, G. and Mukhopadhyay, A.K. (2003) Stimulatory Effect of Progesterone on the Expression of Steroidogenic Acute Regulatory Protein in MA-10 Leydig Cells. Biology of Reproduction, 68, 1054-1063. http://dx.doi.org/10.1095/biolreprod.102.009266

[17] Rossato, M., Nogara, A., Merico, M., Ferlin, A. and Foresta, C. (1999) Identification of Functional Binding Sites for Progesterone in Rat Leydig Cell Plasma Membrane. Steroids, 64, 168-175. http://dx.doi.org/10.1016/S0039-128X(98)00104-4

[18] Cuevas, M.E. and Callard, G. (1992) Androgen and Progesterone Receptors in Shark (Squalus) Testis: Characteristics and Stage-Related Distribution. Endocrinology, 130, 2173-2182.

[19] Thomas, P., Breckenridge-Miller, D. and Detweiler, C. (1997) Binding Characteristics and Regulation of the 17,20 $\beta, 21-$ Trihydroxy-4-pregnen-3-one (20 $\beta$-S) Receptor on Testicular and Sperm Plasma Membranes of Spotted Sea Trout (Cynoscion nebulosus). Fish Physiology and Biochemistry, 17, 109-116. http://dx.doi.org/10.1023/A:1007781128677

[20] D’Aniello, A., Di Cosmo, A., Di Cristo, C., Assisi, L., Botte, V. and Di Fiore, M.M. (1996) Occurrence of Sex Steroid Hormones and Their Binding Proteins in Octopus vulgaris Lam. Biochemical and Biophysical Research Communication, 227, 782-788. http://dx.doi.org/10.1006/bbrc.1996.1585

[21] Zhang, L., Wang, H., Yang, Y., Liu, H., Zhang, Q., Xiang, Q., Ge, R., Su, Z. and Huang, Y. (2013) NGF Induces Adult 
Stem Leydig Cells to Proliferate and Differentiate during Leydig Cell Regeneration. Biochemical and Biophysical Research Communication, 436, 300-305. http://dx.doi.org/10.1016/j.bbrc.2013.05.098

[22] Chambon, P. (1990) Two Distintic Estrogen Promoters Generate Transcripts Encoding the Two Functionally Progesterone Forms A and B. The EMBO Journal, 19, 1603-1614.

[23] Luetjens, C.M., Didolkar, A., Kliesch, S., Paulus, W., Jeibmann, A., Böcker, W., Nieschlag, E. and Simoni, M. (2006) Tissue Expression of the Nuclear Progesterone Receptor in Male Non-Human Primates and Men. Journal of Endocrinol, 189, 529-539. http://dx.doi.org/10.1677/joe.1.06348

[24] Carucci, L.R., Tirkes, A.T., Pretorius, E.S., Genega, E.M. and Weinstein, S.P. (2003) Case Report: Testicular Leydig’s Cells Hyperplasia. MR Imaging and Sonographic Findings. AJR: American Journal of Roentgenology, 180, 501-503. http://dx.doi.org/10.2214/ajr.180.2.1800501

[25] Colecchia, M., Nistal, M., Gonzalez-Peramato, P., Carmignani, L., Salvioni, R., Nicolai, N. and Regadera, J. (2007) Leydig Cell Tumor and Hyperplasia. A Review. Analytical and Quantitative Cytology and Histology, 29, 139-147.

[26] Gonzalez, C.R., Vallcaneras, S.S., Calandra, R.S. and Gonzalez Calvar, S.I. (2013) Involvement of KLF14 and Egr-1 in the TGF-Beta1 Action on Leydig Cell Proliferation. Cytokine, 61, 670-675. http://dx.doi.org/10.1016/j.cyto.2012.12.009

[27] Gonzalez, C.R., Matzkin, M.E., Frungieri, M.B., Terradas, C., Ponzio, R., Puigdomenech, E., Levalle, O., Calandra, R.S. and Gonzalez Calvar, S.I. (2010) Expression of the TGF-Beta1 System in Human Testicular Pathologies. Reproductive Biology and Endocrinology, 8, 148-159. http://dx.doi.org/10.1186/1477-7827-8-148

[28] McLachlan, R.I., Rajpert-De Meyts, E., Hoei-Hansen, C.E., de Kretser, D.M. and Skakkebaek, N.E. (2007) Histological Evaluation of the Human Testis-Approaches to Optimizing the Clinical Value of the Assessment. Human Reproduction, 22, 2-16. http://dx.doi.org/10.1093/humrep/del279

[29] Silber, S.J., Nagy, Z., Devroey, P., Tournaye, H. and Van Steirteghem, A.C. (1997) Distribution of Spermatogenesis in the Testicles of Azoospermic Men: The Presence or Absence of Spermatids in the Testes of Men with Germinal Failure. Human Reproduction, 12, 2422-2428. http://dx.doi.org/10.1093/humrep/12.11.2422

[30] Silber, S.J. and Rodriguez-Rigau, L.J. (1981) Quantitative Analysis of Testicle Biopsy: Determination of Partial Obstruction and Prediction of Sperm Count after Surgery for Obstruction. Fertility and Sterility, 36, 480-485.

[31] Holm, M., Rajpert-De Meyts, E., Andersson, A.-M. and Skakkebæk, N.E. (2003) Leydig Cell Micronodules Are a Common Finding in Testicular Biopsies from Men with Impaired Spermatogenesis and Are Associated with Decreased Testosterone/LH Ratio. Journal of Pathology, 199, 378-386. http://dx.doi.org/10.1002/path.1309

[32] Pfaffl, M.W. (2001) A New Mathematical Model for Relative Quantification in Realtime RT-PCR. Nucleic Acids Research, 29, 45e-45. http://dx.doi.org/10.1093/nar/29.9.e45

[33] Meeker, J.D., Ehrlich, S., Toth, T.L., Wright, D.L., Calafat, A.M., Trisini, A.T., Ye, X. and Hauser, R. (2010) Semen Quality and Sperm DNA Damage in Relation to Urinary Bisphenol A among Men from an Infertility Clinic. Reproductive Toxicology, 30, 532-539. http://dx.doi.org/10.1016/j.reprotox.2010.07.005

[34] Toppari, J., Larsen, J.C., Christiansen, P., Giwercman, A., Grandjean, P., Guillette Jr., L.J., Jégou, B., Jensen, T.K., Jouannet, P., Keiding, N., Leffers, H., McLachlan, J.A., Meyer, O., Müller, J., Rajpert-De Meyts, E., Scheike, T., Sharpe, R., Sumpter, J. and Skakkebaek, N.E. (1996) Male Reproductive Health and Environmental Xenoestrogens. Environmental Health Perspectives, 104, 741-803. http://dx.doi.org/10.1289/ehp.96104s4741

[35] Toppari, J., Virtanen, H.E., Main, K.M. and Skakkebaek, N.E. (2010) Cryptorchidism and Hypospadias as a Sign of Testicular Dysgenesis Syndrome (TDS): Environmental Connection. Birth Defects Research. Part A: Clinical and Molecular Teratology, 88, 910-919. http://dx.doi.org/10.1002/bdra.20707

[36] Sirianni, R., Chimento, A., De Luca, A., Zolea, F., Carpino, A., Rago, V., Maggiolini, M., Andò, S. and Pezzi, V. (2009) Inhibition of Cyclooxygenase-2 Down-Regulates Aromatase Activity and Decreases Proliferation of Leydig Tumor Cells. Journal of Biologycal Chemistry, 284, 28905-28916. http://dx.doi.org/10.1074/jbc.M109.041020

[37] Carreau, S., Lambard, S., Delalande, C., Denis-Galeraud, I., Bilinska, B. and Bourguiba, S. (2003) Aromatase Expression and Role of Estrogens in Male Gonad: A Review. Reproductive Biology and Endocrinology, 1, 35. http://dx.doi.org/10.1186/1477-7827-1-35

[38] Lardone, M.C., Castillo, P., Valdevenito, R., Ebensperger, M., Ronco, A.M., Pommer, R., Piottante, A. and Castro, A. (2010) P450-Aromatase Activity and Expression in Human Testicular Tissues with Severe Spermatogenic Failure. International Journal of Andrology, 33, 650-660. http://dx.doi.org/10.1111/j.1365-2605.2009.01002.x

[39] Li, X., Nokkala, E., Yan, W., Streng, T., Saarinen, N., Warri, A., Huhtaniemi, I., Santti, R., Makela, S. and Poutanen, M. (2001) Altered Structure and Function of Reproductive Organs in Transgenic Male Mice Overexpressing Human Aromatase. Endocrinology, 42, 2435-2442.

[40] Abney, T.O. (1999) The Potential Roles of Estrogens in Regulating Leydig Cell Development and Function: A Review. Steroids, 64, 610-617. http://dx.doi.org/10.1016/S0039-128X(99)00041-0 
[41] Mäkinen, S., Mäkelä, S., Weihua, Z., Warner, M., Rosenlund, B., Salmi, S., Hovatta, O. and Gustafsson, J.A. (2001) Localization of Oestrogen Receptors Alpha and Beta in Human Testis. Molecular Human Reproduction, 7, 497-503. http://dx.doi.org/10.1093/molehr/7.6.497

[42] Saunders, P.T., Sharpe, R.M., Williams, K., Macpherson, S., Urquart, H., Irvine, D.S. and Millar, M.R. (2001) Differential Expression of Oestrogen Receptor Alpha and Beta Proteins in the Testes and Male Reproductive System of Human and Non-Human Primates. Molecular Human Reproduction, 7, 7-36. http://dx.doi.org/10.1093/molehr/7.3.227

[43] Arnal, J.F., Gourdy, P. and Lenfant, F. (2013) In Vivo Dissection of the Estrogen Receptor Alpha: Uncoupling of Its Physiological Effects and Medical Perspectives. Annals of Endocrinology (Paris), 74, 82-89. http://dx.doi.org/10.1016/j.ando.2013.03.001

[44] Prossnitz, E.R. and Maggiolini, M. (2009) Mechanisms of Estrogen Signaling via GPR30. Molecular Cellular Endocrinology, 308, 32-38. http://dx.doi.org/10.1016/j.mce.2009.03.026

[45] Albanito, L., Lappano, R., Madeo, A., Chimento, A., Prossnitz, E.R., Cappello, A.R., Dolce, V., Abonante, S., Pezzi, V. and Maggiolini, M. (2008) G-Protein-Coupled Receptor 30 and Estrogen Receptor-Alpha Are Involved in the Proliferative Effects Induced by Atrazine in Ovarian Cancer Cells. Environmental Health Perspectives, 116, 1648-1655. http://dx.doi.org/10.1289/ehp.11297

[46] Kauffman, E.C., Robinson, B.D., Downes, M., Marcinkiewicz, K., Vourganti, S., Scherr, D.S., Gudas, L.J. and Mongan, N.P. (2013) Estrogen Receptor- $\beta$ Expression and Pharmacological Targeting in Bladder Cancer. Oncology Reports, 30, 131-138. http://dx.doi.org/10.3892/or.2013.2416

[47] Carpino, A., Rago, V., Pezzi, V., Carani, C. and Andò, S. (2007) Detection of Aromatase and Estrogen Receptors (ERa, ERb1, ERb2) in Human Leydig Cell Tumor. European Journal of Endocrinology, 157, 239-244. http://dx.doi.org/10.1530/EJE-07-0029

[48] Du Mond Jr., J.W., Singh, K.P. and Roy, D. (2001) The Biphasic Stimulation of Proliferation of Leydig Cells by Estrogen Exposure. International Journal of Oncology, 18, 623-628.

[49] Gonzalez, C.R., Calandra, R.S. and Gonzalez-Calvar, S.I. (2013) Testicular Expression of the TGF- $\beta 1$ System and the Control of Leydig Cell Proliferation. Advances in Bioscience and Biotechnology, 4, 1-7. http://dx.doi.org/10.4236/abb.2013.410A4001 
Scientific Research Publishing (SCIRP) is one of the largest Open Access journal publishers. It is currently publishing more than 200 open access, online, peer-reviewed journals covering a wide range of academic disciplines. SCIRP serves the worldwide academic communities and contributes to the progress and application of science with its publication.

Other selected journals from SCIRP are listed as below. Submit your manuscript to us via either submit@scirp.org or Online Submission Portal.
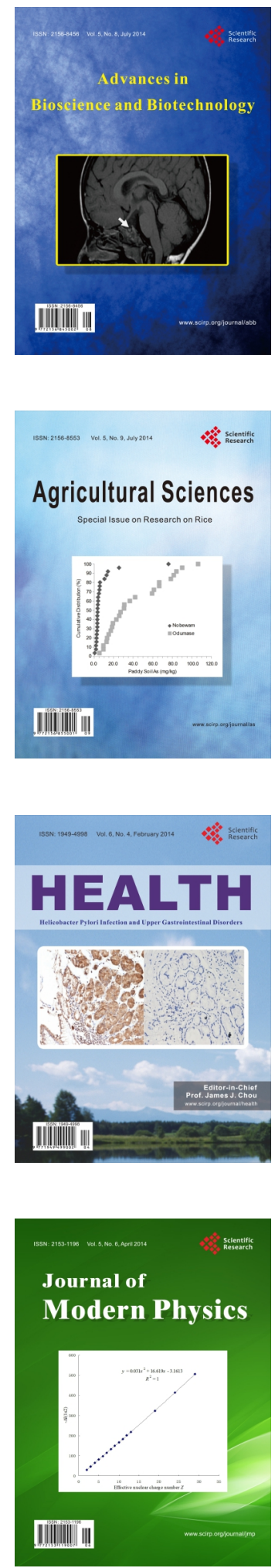
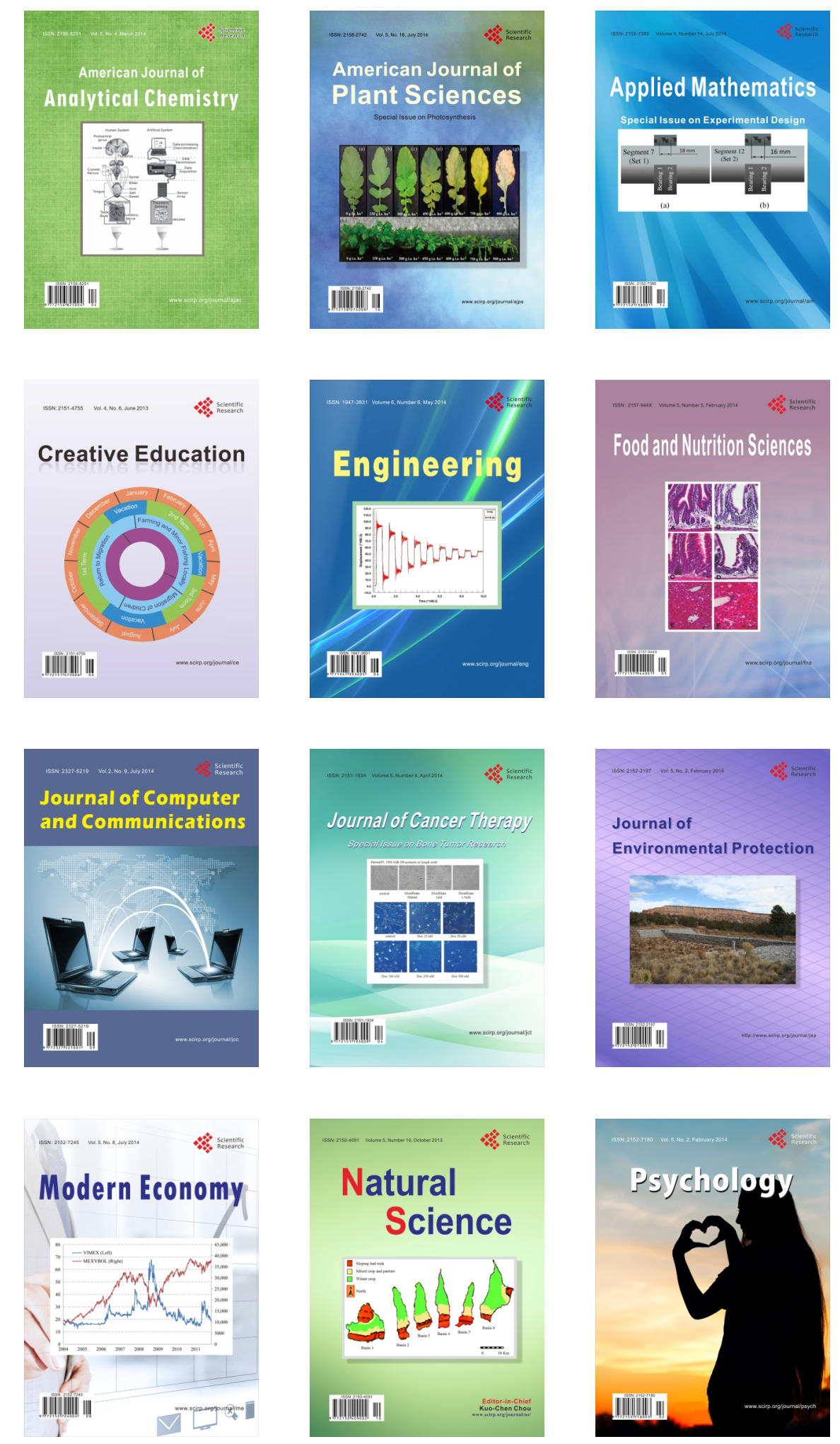